\title{
Staphylococcus epidermidis glucose uptake in biofilm versus planktonic cells
}

\author{
Cláudia Sousa $\cdot$ Mariana Henriques $\cdot$ \\ Joana Azeredo $\cdot$ Pilar Teixeira $\cdot$ Rosário Oliveira
}

Received: 16 May 2006/Accepted: 3 June 2007/Published online: 15 July 2007

(C) Springer Science+Business Media B.V. 2007

\begin{abstract}
The aim of this work was to compare the glucose uptake of biofilms formed by four different Staphylococcus epidermidis strains as well as to compare between sessile and planktonic cells of the same strain. Biofilm cells showed a lower level of glucose uptake compared to planktonic cells. Moreover, glucose uptake by cells in the sessile form was strongly influenced by biofilm composition. Therefore, this work helps to confirm the phenotypic variability of $S$. epidermidis strains and the different behaviour patterns between sessile and free cells.
\end{abstract}

Keywords Biofilms · Glucose uptake · Planktonic cells · Staphylococcus epidermidis

\section{Introduction}

Staphylococcus epidermidis is a coagulase-negative staphylococcus (CNS) that is one of the main nosocomial pathogens associated with infections of implanted medical devices (Von Eiff et al. 2002). CNS adheres to such devices and has the ability to form biofilms which constitutes one important virulence factor and is considered the main responsible for S. epidermidis pathogenesis (Henning et al. 2007). Bacteria in biofilms are more resistant $(1,000$ up fold) to antibiotics and to the host immune defence system than their planktonic counterparts (Cerca et al. 2005), suggesting that cells in a biofilm may have altered meta-

C. Sousa $\cdot$ M. Henriques $\cdot$ J. Azeredo $\cdot$ P. Teixeira $(\square)$.

R. Oliveira

IBB-Institute for Biotechnology and Bioengineering, Centre for

Biological Engineering, Universidade do Minho, Campus de Gualtar, 4710-057 Braga, Portugal

e-mail: pilar@deb.uminho.pt bolic activity (Resch et al. 2005). This strong resistance regularly requires the removal of the infected biomaterial and leads to substantial morbidity and mortality (Mack et al. 2004). Thus, it is extremely important to know the essential differences, especially concerning physiology and metabolic activity, between a planktonic cell and its sessile counterpart adhered to a surface living in a biofilm.

The aim of this work was to compare the glucose uptake of biofilms formed by four different $S$. epidermidis strains, and between sessile and planktonic cells of the same strain. Thus, the influence of biofilm characteristics such as total biomass formed, cell concentration and polysaccharides content on the glucose uptake was also evaluated.

\section{Materials and methods}

All strains used in this work (LE7, 9142, IE186 and IE214) are clinical isolates and were kindly provided by DR. G. B. Pier, Channing Laboratory, Department of Medicine, Brigham and Women's Hospital, Harvard Medical School, Boston.

For all the biofilm assays, cells were first grown for $24 \mathrm{~h}$ in $15 \mathrm{ml}$ of TSB (Merck, Darmstadt, Germany) at $37^{\circ} \mathrm{C}$ using an orbital shaker (130 rev/min). After this period, $50 \mu$ of each suspension were transferred to $30 \mathrm{ml}$ of fresh TSB broth and incubated for $18 \mathrm{~h}$ (late exponential phase), at $37{ }^{\circ} \mathrm{C}$ and $130 \mathrm{rev} / \mathrm{min}$. Then, the cells were centrifuged (Sigma 4K10, B. Braun, Germany) for $5 \mathrm{~min}$, at $10,500 \mathrm{~g}$ and $4{ }^{\circ} \mathrm{C}$, washed twice with a saline solution $(0.9 \% \mathrm{NaCl}$ (Merck) in distilled water), and sonicated (Ultrasonic Processor, Cole-Parmer, Illinois, USA) during $10 \mathrm{~s}$, with an amplitude of $22 \%$ (previously optimized to avoid cell disruption). The cellular suspension was adjusted to a final concentration of approximately $1 \times 10^{9}$ cells $/ \mathrm{ml}$, determined 
by optical density at $640 \mathrm{~nm}$. Acrylic was used as substratum and cut into $2 \mathrm{~cm} \times 2 \mathrm{~cm}$ squares. Prior to use, the coupons were washed with sterile distilled water and with a solution of $70 \%$ ethanol diluted in sterile distilled water. Each clean acrylic coupon was placed into an individual well of a 6-well tissue culture plate (Sarstedt, Newton, NC, USA) containing $5 \mathrm{ml}$ of TSB enriched with $0.25 \%$ of glucose (Merck). For every strain, an inoculum of $50 \mu \mathrm{l}$ with $1 \times 10^{9}$ cells $/ \mathrm{ml}$ was added to each well. Assays were performed in triplicate and repeated 3 times. The plates were incubated for $192 \mathrm{~h}$ (eight days) at $37{ }^{\circ} \mathrm{C}$ in an orbital shaker (120 rev/min). The medium was withdrawn and replaced by fresh TSB $+0.25 \%$ glucose every $12 \mathrm{~h}$ (fedbatch mode). The total attached biomass to the acrylic coupons was measured by methanol fixation, crystal violet staining and acid acetic elution as previously described (Stepanović et al. 2000). The eluted dye of each well was removed and placed in a 96-well microtitre plate (Sarstedt, Newton, NC, USA) and its absorbance was read in an ELISA reader (Bio-Tek Instruments Inc., Vermont, USA) at $570 \mathrm{~nm}$. In order to determine the biofilm cell concentration, the acrylic coupons with biofilm were washed twice with $\mathrm{NaCl} 0.9 \%$. Then, the biofilm was removed from the coupons by scrapping with a spatula and resuspended into $25 \mathrm{ml}$ of TSB $+0.05 \%$ Tween 20 (Merck). Next, the suspension was sonicated ( $20 \mathrm{~s}$ with $22 \%$ of amplitude), centrifuged $\left(5 \mathrm{~min}, 10,500 \mathrm{~g}, 4{ }^{\circ} \mathrm{C}\right)$, resuspended in $30 \mathrm{ml}$ of $\mathrm{NaCl} 0.9 \%$ and sonicated again (10 s, $22 \%$ amplitude) to promote biofilm disruption. The absorbance was read at $640 \mathrm{~nm}$. The number of c.f.u in biofilm for each S. epidermidis strain was determined by plating onto TSA in triplicate using decimal dilutions and incubating for 24-48 h. The extraction of the exopolymeric matrix, for the quantification of the polysaccharides, was assessed using the Dowex resin extraction method as described by Azeredo et al. (2003). The biofilm matrix polysaccharides were quantified by the method of Dubois et al. (1956). In order to determine the glucose uptake in the biofilm and to remove the cells loosely attached and residual medium, each coupon was consecutively transferred to three $100 \mathrm{ml}$ glass beakers containing distilled water, and was allowed to rest there for approximately $10 \mathrm{~s}$. Then the coupons were transferred to a new 6-well tissue plate containing $5 \mathrm{ml}$ of $0.10 \%$ glucose solution $(\mathrm{w} / \mathrm{v})$. The glucose concentration in the medium was measured immediately after transferring the coupons and also 60 min later, maintaining the plates under slow agitation. Glucose was quantified with the enzymatic kit Glucose-TR (Spinreact, SA, Spain) using the ELISA reader at $505 \mathrm{~nm}$.

For the assays to determine the glucose uptake by the planktonic cells, all strains were incubated in $15 \mathrm{ml}$ of TSB and grown for $24( \pm 2) \mathrm{h}$ at $37{ }^{\circ} \mathrm{C}$ in an orbital shaker (130 rev/min). Then, $100 \mu \mathrm{l}$ of each cell suspension were transferred to $60 \mathrm{ml}$ of fresh TSB and incubated for $18 \mathrm{~h}$ (to reach late exponential phase) at $37{ }^{\circ} \mathrm{C}$ and $130 \mathrm{rev} / \mathrm{min}$. Cells were harvested by centrifugation (for $5 \mathrm{~min}$ at $10,500 \mathrm{~g}$ and $4{ }^{\circ} \mathrm{C}$ ) and resuspended in TSB to the same concentration as previously determined by c.f.u. plating of biofilm cells. For all strains, $1 \mathrm{ml}$ of the suspension obtained was centrifuged at $9,500 \mathrm{~g}$ and the pellet resuspended in $1 \mathrm{ml}$ of $0.10 \%$ glucose solution. These samples were then transferred to the wells of a 6-well tissue culture plate containing $4 \mathrm{ml}$ of $0.10 \%$ glucose solution. Glucose present in the medium was measured at time zero and after 60 min with the enzymatic kit Glucose-TR, as described for biofilm assays.

The data obtained was analyzed using a statistical program, SPSS (Statistical Package for the Social Sciences). One-way ANOVA with Tukey test was used to compare the results of the different assays. All tests were performed with a confidence level of $95 \%$.

\section{Results and discussion}

In this study, strain variability in terms of biofilm formation ability was assessed through the crystal violet assay (Fig. 1) and the data obtained revealed a significantly $(p<0.05)$ higher ability of biofilm formation by strains 9142, IE186, IE214 in contrast to strain LE7. This shows that crystal violet staining is a reliable method, having the advantage of being easy and expedite, i.e., providing the results almost immediately, with a great objectivity and accuracy. The assays to determine the glucose uptake by cells in suspension were performed with the same cellular concentration of the biofilm assays. This cellular concentration was determined by c.f.u. plating of the biofilm cells, in terms of c.f.u./ml, for the four S. epidermidis strains. Strain 9142 presented the highest cellular concentration $\left(1.5 \times 10^{18}\right.$ c.f.u. $\left./ \mathrm{ml}\right)$ in comparison with strains IE214

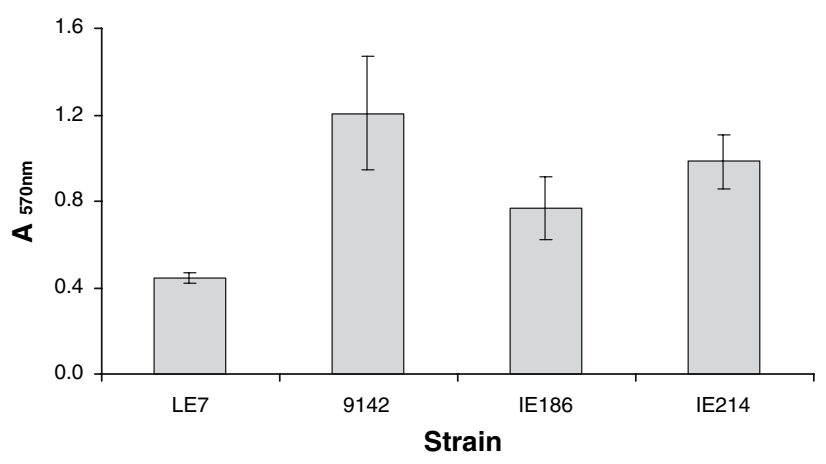

Fig. 1 Biofilm biomass of four Staphylococcus epidermidis strains, accumulated over $192 \mathrm{~h}$, expressed as crystal violet absorbance $\left(\mathrm{A}_{570 \mathrm{~nm}}\right)$. Results represent means plus standard deviations (errors bars) from three independent experiments 
$\left(2.7 \times 10^{17}\right.$ c.f.u./ml $)$ and IE186 $\left(3.9 \times 10^{17}\right.$ c.f.u./ml $)$. The number of cells on LE7 biofilms was very low $\left(6.5 \times 10^{16}\right.$ c.f.u./ml $)$ compared to the other three strains which are strong biomass producers (Fig. 1). As far as the amount of polysaccharides present in the polymeric matrix is concerned, strain IE214 produced the largest amount of

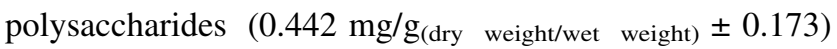
and this is the most likely explanation for the large value of its total biomass production. In the same way, LE7 was the strain that produced the smallest amount of polysaccharides $\left(0.189 \mathrm{mg} / \mathrm{g}_{(\mathrm{dw} / \mathrm{ww})} \pm 0.045\right)$ and is the one that produced the least quantity of total biomass. Strain 9142 and strain IE186 presented intermediary values, $0.378 \mathrm{mg} / \mathrm{g}_{(\mathrm{dw} /}$ ww) \pm 0.172 and $0.228 \mathrm{mg} / \mathrm{g}_{(\mathrm{dw} / \mathrm{ww})} \pm 0.092$, respectively. The present study shows that biofilm glucose uptake can differ between strains of the same species (Fig. 2). In absolute terms, strain 9142 biofilms removed from the liquid phase the highest amount of glucose (23.98\%), followed by the biofilms of strains IE186 (12.7\%) and IE214 $(8.29 \%)$, while strain LE7 displayed a significantly less glucose uptake $(1.11 \%)$. These results correlate with the number of c.f.u./ml in the biofilms. This is also in agreement with previous studies that showed that the amount of biofilm produced by individual $S$. epidermidis strains is highly variable phenotypically and regulated by several factors (Cramton et al. 2001; Mack et al. 2004). The percentage of glucose uptake by planktonic cells (Fig. 2) shows the same tendency but is significantly higher than their biofilm counterparts. This would be expected because it has already been shown that cells in sessile form display a lower metabolic activity (Walters et al. 2003). The reduction of the percentage of glucose uptake from planktonic cells to biofilm cells is on average twofold for the three highest biofilm producing strains. Low levels of glucose uptake might be an indicative of a lower metabolic activity and consequently slow growth has been considered

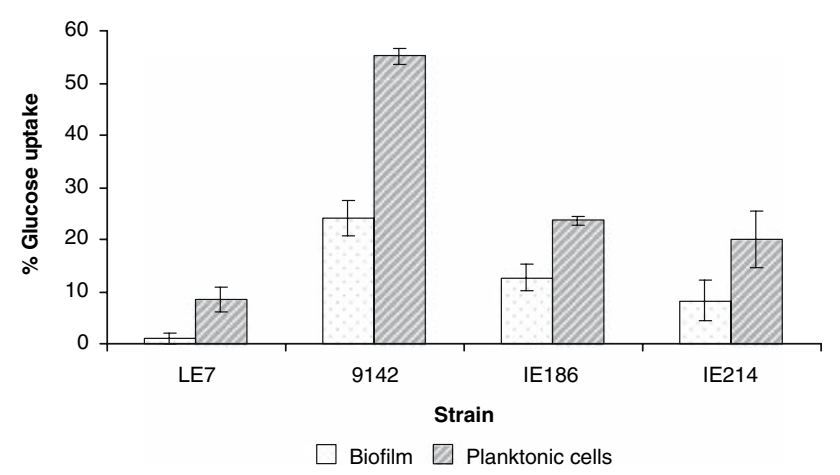

Fig. 2 Glucose uptake expressed in \% for the four Staphylococcus epidermidis strains in biofilm and in the planktonic form. Results represent means plus standard deviations (errors bars) from three independent experiments one of the main reasons for biofilm resistance and success against antimicrobial agents (Fux et al. 2005). Biofilms cells are immersed in a matrix which provides the bacterial population protection from the host defence mechanisms and antimicrobial agents. In addition, the surface attached populations are exposed to a different nutrient environment than the planktonic cells (Møller et al. 1995). Thus, many factors may affect the response of biofilm cells in terms of metabolic activity and antibiotic susceptibility.

\section{Conclusions}

This study shows that the determination of glucose uptake by cells in suspension and in biofilm is an expedite method to evaluate the different behaviour of $S$. epidermidis strains in both forms. According to the results obtained, the four $S$. epidermidis strains revealed different abilities of biofilm formation, with sessile cells displaying lower glucose uptake in comparison to planktonic cells for all the strains studied. In the sessile form, glucose uptake seems to be dependent on the strain specific properties of the biofilm such as the cell concentration and the production of extracellular matrix.

Acknowledgements The authors acknowledge the financial support of FCT, through the project POCTI/ESP/42688/2001 and the grant SFRH/BD/19265/2004. The authors also acknowledge to Anthony Danko for his precious help in the improvement of the manuscript.

\section{References}

Azeredo J, Henriques M, Sillankorva S, Oliveira R (2003) Extraction of exopolymers from biofilms: the protective effect of glutaraldehyde. Water Sci Technol 47:175-179

Cerca N, Martins S, Cerca F, Jefferson KK, Pier GB, Oliveira R, Azeredo J (2005) Comparative assessment of antibiotic susceptibility of coagulase-negative staphylococci in biofilm versus planktonic culture as assessed by bacterial enumeration or rapid XTT colorimetry. J Antimicrob Chemother 56:331-336

Cramton SE, Gerke C, Götz F (2001) In vitro methods to study staphycococcal biofilm formation. Methods Enzymol 336:239255

Dubois M, Gilles KA, Hamilton JK, Rebers PA, Smith F (1956) Colorimetric method for determination of sugars and related substances. Anal Chem 28:350-356

Fux CA, Costerton JW, Stewart PS, Stoodley P (2005) Survival strategies of infectious biofilms. Trends Microbiol 13:34-40

Hennig S, Wai SN, Ziebuhr W (2007) Spontaneous switch to PIAindependent biofilm formation in an ica-positive Staphylococcus epidermidis isolate. Int J Med Microbiol 297:117-122

Mack D, Becker P, Chatterjee I, Dobinsky S, Knobloch JK-M, Peters G, Rohde H, Herrmann M (2004) Mechanisms of biofilm formation in Staphylococcus epidermidis and Staphylococcus aureus: functional molecules, regulatory circuits, and adaptive responses. Int J Med Microbiol 294:203-212

Møller S, Kristensen CS, Poulsen LK, Carstensen JM, Molin S (1995) Bacterial growth on surfaces: automated image analysis for 
quantification of growth rate-related parameters. Appl Environ Microbiol 61:741-748

Resch A, Rosenstein R, Nerz C, Gotz F (2005) Differential gene expression profiling of Staphylococcus aureus cultivated under biofilm and planktonic conditions. Appl Environ Microbiol 71:2663-2676

Stepanović S, Vuković D, Dakić I, Savić B, Švabić-Vlahović M (2000) A modified microtiter-plate test for quantification of staphylococcal biofilm formation. J Microbiol Methods 40:175-179
Von Eiff C, Peters G, Heilmann C (2002) Pathogenesis of infections due to coagulase-negative staphylococci. Lancet Infec Dis 2:677-685

Walters III MC, Roe F, Bugnicourt A, Franklin MJ, Stewart PS (2003) Contributions of oxygen limitation, and low metabolic activity to tolerance of Pseudomonas aeruginosa biofilms to ciprofloxacin and tobramycin. Antimicrob Agents Chemother $47: 317-323$ 